\title{
Minority languages and linguistic policy in the Republic of Serbia
}

\author{
Olga A. Lysenko - Oksana V. Tretyakova
}

\section{DOI: 10.18355/XL.2017.10.03.28}

\begin{abstract}
The article presents a review of the recent language policy introduced by the Serbian government regarding minority languages and the Slovenian in particular against the background of negative demographic trends for the Slovenes. The Republic of Serbia is considered a final successor-state of the SFRY, there are also parallels drawn with the language policy of the SFRY and a status of the Serbs in the Republic of Slovenia. Based on the problems identified in the Serbian system of justice, there is a conclusion that at the legislation level measures taken by the Serbian government as its language policy might be called consistent, whereas in praxi there is a number of unsolved problems.
\end{abstract}

Key words: Slovenian, Slovenes, Republic of Serbia, language policy, national minority

\section{Introduction}

Disintegration of the SFRY in the Balkans in 1991 brought changes in a national structure of individual countries, a status of languages, changes in languages themselves, and even establishment of languages that were formally called 'new' (Montenegrin, Bosnian). Therefore, it is not surprising that such an interest in problems of the region has been obvious in recent years among philologists, sociolinguists, political scientists, historians, and other experts. In view of this, with an example of today's Slovenian we will review the language policy in the Republic of Serbia. In such a case, we consider this country as a final legal successor of the SFRY according to norms fixed in international and national legislation.

\section{Review of literature}

The theoretical foundation for this research includes conclusions about the language policy as a set of practical measures taken by a government about a status of a state language with its functions and dominating role, an exclusive or non-exclusive usage in the most important fields in the society, and controlled involvement of other languages (Belikov and Krysin, 2001). In this case, among the tools, there are legislative acts based on expert knowledge on a use of language and its capacities to serve one or another sphere in the public life.

The language policy can be viewed as any decisions about any language, its controlled use within a particular area by an authorized state authority (Rousseau, 2007). Some researchers make a special emphasis on its purpose: saved current state of a language and its change according to needs of the society or time in general (neologisms, renewed national traditions) (Schweitzer, 1978).

It should be mentioned that even if the government does not take expressive measures in the language policy, people might support or suppress distribution of any language in laws on education and the media. There is also the concept of the 'spontaneous' language policy that can be found in the economic turnover and in development of market relations (Alpatov, 2013). Some researchers associate linguistic pluralism in the developed countries in recent decades with a transition from the industrial to the post-industrial society thinking that it is today impossible to see essential changes in the developed countries in their language policies. Otherwise, it

XLinguae Journal, Volume 10 Issue 3, June 2017, ISSN 1337-8384 
might result in mutual misunderstanding between citizens in a country (Alpatov, 2013).

The language policy essentially settles a set of problems associated with functioning of the language in the today's society and these problems cannot always be attributed to a range of cross-cultural or narrowly linguistic problems. In this regard, in some papers among the reviewed sources their authors are discussing relationships between nationalism, language, and war, which are particularly obvious in major political events, such as a collapse of Yugoslavia that did not only led to appearance of new states, but also new languages (Bugarski, 2002; Bugarski, 2014).

With reference to this position and based on the systematic approach, there is another attempt to develop a complete and impersonal sociolinguistic image for the area in question. Thus, for example, linguistic and socio-linguistic changes in countries that have appeared upon disintegration of the SFRY for the past twenty years, an attitude towards a native language, its variants, its relationship towards other languages (languages of other peoples and national minorities), (un)necessary linguistic changes, an overall ratio between the language policy and the language reality are discussed in the co-authored monograph (Požgaj Hadži, 2013) under the large-scale joint project and bilateral agreements between states in the region.

The book emphasizes constant interactions and 'weavings' between languages and politics. This is expressed, first, in the fact that politics always influences codification and standardization of the language. Secondly, in the fact that in some cases the declared language policy is completely different from the linguistic reality (Požgaj Hadži, 2013).

It should be also mentioned that some other reviewed sources that declare an attempt to analyse the current condition of the language policy in Serbia reduce a discussion to some special points like threats observed by authors specifically for further development or degradation of Serbian and an actual gradual and conscious, even forced, withdrawal of the Cyrillic alphabet from usage (Vojvodić, 2015; Marjanović, 2016; Srpski Jezik i Jezička Politika 2015). They analyse reasons for this, find them in the language policy of the SFRY and predict linguistic and cultural consequences. They say nothing about other languages.

A number of authors restore a picture of the language policy in detail saying about legislation and implementation of guaranteed rights with examples of several ethnic groups (Bašić and Đorđević, 2010). Unfortunately, there are no the Slovenes in these surveys, probably because of their small number in the demographic picture of the population in the Republic of Serbia (see Table 1 and Fig. 1).

Summarizing ideas of their colleagues about the Serbian language policy, others propose to seek a new vector: consider globalization processes more than before going from conventional nationalism typical for European national countries (Filipović, 2008; Bugarski, 2002; Bugarski, 2014).

\section{Materials and methods}

The language in the framework of this discussion is not seen as an isolated phenomenon. It is not only understood as a tool for written and oral communication. It might be also associated with issues of national safety and dangerous manifestations of nationalism (Bugarski, 2014), as a proactive tool to somehow disrupt a political situation in the country.

We applied abstracting and generalization methods to the group of sources in foreign languages and the comparative method as an auxiliary to collate today's language policies in the Republic of Serbia, on the one hand, and the Republic of Slovenia, on the other hand. We also involved SFRY experience of dealing with problems in its language policy. 


\section{Results}

Legacy of the SFRY

The Republic of Serbia is a final legal successor of the SFRY. Socialist Yugoslavia had declared the policy of national and linguistic unity. It means declared and de facto equality of all the languages, regardless of a number of their speakers, without preferences or dominance of one of them. This is not surprising as in the country according to the census of 1981, there were 22.4 million people, two alphabets, three religions, five literary languages, six nations, more than a dozen of ethnic minorities and six republics within the federal structure. The country's population spoke more than twenty languages. They differed by their geographical distribution, ethnicity, standardization, and image. $73 \%$ citizens spoke SerboCroatian, bilingualism and multilingualism were widespread, especially in multiethnic areas, like autonomous provinces of Vojvodina and Kosovo. Representatives of national minorities used either Serbo-Croatian, or native languages.

In Yugoslavia, the Slovenes were among constituent (title) nations together with the Serbs, the Croats, the Macedonians, the Muslimani (the Muslims in the sense of nations). These five nations were proportionally represented at all levels of governance, starting from local authorities. They had a right to their mother tongue as an official and cultural autonomy (establish societies and cultural institutions and teaching in their native languages as well).

Experts say the language policy in the SFRY was successful, although it did not go without numerous problems in implementation. Among them, there were specific language and cultural separatism in Slovenia and Croatia in the 1960-ies (Bugarski, 2014).

At the same time, not all the researchers agree with this view on successes of the language policy in Yugoslavia. They mean Serbo-Croatian in Slovenia prior to the breakdown of the SFRY. They say that in some areas it had a status and reputation of a dominant language with a de-privileged role of Slovenian in the linguistic reality in spite of its formal legal status as an official language in Slovenia. In contrast, in the nineties, in the Slovenian society, Serbo-Croatian had an extremely negative informal status with its disappearance from high schools as a subject and with stigmatization of its speakers (Požgaj Hadži, 2013).

Today's demographic situation

Disintegration of SFRY changed the ratio of national minorities and constituent nations. In this process, the Slovenes lost their status of a constituent nation and received a status of a national minority. Protection of their rights was guaranteed as early as by the Constitution in the 1990-ies, but in fact, these provisions were not complied with. Mechanisms and tools to finance institutions, societies, and associations responsible for implementation of guaranteed rights for national minorities were destroyed.

As for the today's demographic situation, the 2011 census established that Serbia is home to 21 ethnic groups. This number only includes groups with more than two thousand representatives each (Vlada Republike Srbije, 2004; Republički zavod za statistiku, 2016). It should be mentioned that the census in that case excluded population from Kosovo.

Among the ethnic groups as early as in 2002, 20 groups had the status of a national minority. Researchers say about prevailing homogeneity of living for national minorities (except for the Romany) (Gojković).

The Slovenes in Serbia since 1948

Ethnostatistical information about the Slovenes in Serbia has been available based on data from censuses since 1948 and demographic statistics since 1957. In the 
second half of the twentieth century, there was a continuous drop in a number of the Slovenes in Serbia like of other national groups in this country (see Table 1). In 2012, having studied demographic data for many years, Knežević concluded about negative dynamics in the natural population growth for the Slovenes starting from as early as 1960. The average age of the Slovenes was 54.9 (as of 2012). Therefore, he points out to a pronounced biological depopulation and demographic aging, which makes a threat to a survival of this nation in the area in question. This is facilitated by no migration of the Slovenes to Serbia and recent active migrations of the labour pool in their reproductive age to Slovenia (Knežević, 2012).

\begin{tabular}{|l|r|r|r|r|r|r|r|r|}
\hline Indicator & 1948 & 1953 & 1961 & 1971 & 1981 & 1991 & 2002 & 2011 \\
\hline $\begin{array}{l}\text { Slovenes, } \\
\text { persons }\end{array}$ & 20,99 & 20,71 & 19,95 & 15,95 & 12,00 & 8,00 & 5,10 & 4,03 \\
1 & 7 & 7 & 6 & 1 & 3 \\
\hline $\begin{array}{l}\text { Slovenes, } \\
\%\end{array}$ & 0.32 & 0.30 & 0.26 & 0.19 & 0.13 & 0.10 & 0.07 & 0.06 \\
\hline
\end{tabular}

Table 1: Slovene population by ethnicity, as per the 1948-2011 censuses (Lakčević et al., 2012)

In time of the census survey of 2011, in the Republic of Serbia 4,033 persons or $0.06 \%$ called themselves as Slovenes (Lakčević et al., 2012; Republički zavod za statistiku, 2016) and it is shown in Table 1. De jure, they have a status of a national minority. In Belgrade, since 2010, the National Council of the Slovenian National Minority (popular assembly) has been working. It includes 13 societies representing all areas with the Slovene population (see Fig. 1). This is a supreme representative body of the Slovenes in the country. It also protects their interests in the field of an official use of the language. It closely collaborates with the government to protect rights of the Slovenes in politics, culture, and education. The Serbian parliament also has quotas provided for representatives of national minorities, including the Slovenes (Ismailov, 2008).

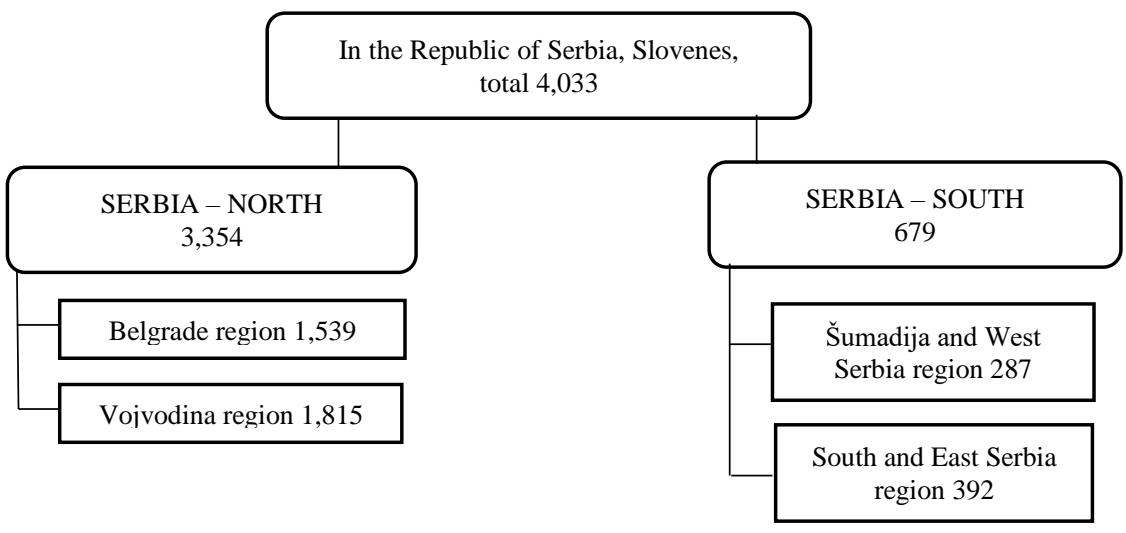

Figure 2: Slovene population by area, as per the 2011 census, persons (Lakčević et al., 2012) 
It should be mentioned that to obtain a status of a national minority, it is not only a number of an ethnic groups that matters, but also some other factors. An ethnocultural group should have long-term relations with the territory of the Republic of Serbia, differ from the dominant population by language, religion, customs, culture as a whole, ethnicity, and origin. Such the group must also demonstrate its clear and strong will to preserve and promote its national identity. Moreover, censuses results show that citizens can hide their national identity and identify themselves by regional affiliation (e.g., results of 2002 census).

Native language and its use to protect minorities' rights

A number of legislative acts passed in different times in 2000-ies about protection of rights and freedoms, an official use of languages and alphabets, teaching in native languages and local self-government, governs rights of minorities. There is also a number of bilateral treaties on protection for minorities signed with Croatia, Macedonia, Hungary, and Romania.

Within cultural autonomy a national minority has a right to protection of its collective identity using a guaranteed right to use a language and an alphabet, education in a native language, a use of first and last names, establish private educational establishments, preserve and develop languages, religions, cultures and national symbols with no risks to country symbols.

The legislation about an official use of a language and an alphabet envisages that if more than $15 \%$ of the population in a particular community belongs to a national minority and traditionally lives in a given area, then their language and their alphabet are mandatory as official, i.e., are to be used in administrative and court proceedings, in contacts with state authorities, in time of registration of personal names in national registers and books, in activities of elective bodies, in time of suggestion of titles for local self-governance institutions, and toponyms. Moreover, the law of the identity card of 2006 provides its printing in a language of a national minority (Gojković).

Slovenian learnt in Serbia

At the University of Belgrade the Slovenian literature and language have been taught over a hundred of years, there is a Slovenian-born lecturer of Slovenian, a rich library has been also collected. From 1947 to 1990, Slovenian had a status of a compulsory course at two university chairs. Later, without any formal resolutions the status of these courses was changed for a variety of reasons. Slovenian became an elective course for students with Serbian as a major at University of Belgrade and the University of Novi Sad. In recent years, an interest in the Slovenian language has to some extent increased, also owing to Slovenia's EU membership, its economic situation, migration, labour market needs, and reforms in education that promote individual educational paths. Slovene as a foreign language is also learnt outside major national universities: courses under advanced training, language schools, and Slovenian societies in Belgrade, Novi Sad, Subotica, Niš, and Zrenjanin (Đukanović). Legislation vs. real life

In view of the abovementioned, the Republic of Serbia is a legal successorstate in the language policy of language equality. Based on some classifications (like Schweitzer, 1978) by type this current language policy towards Slovenian as a language of a minority group could be described as forward-looking and constructive despite negative demographic trends.

However, in spite of all the above mentioned and promising legislation, the real cases do not keep pace with laws. For example, in the judicial system, at the level of certain communities based on acts of law passed by local governments, pools of court interpreters are established for those languages of national minorities, which 
have been declared official or formal (amendments to statutes of communities, decrees made by local parliaments) at a certain community. At the same time, a lack of sign language interpreters and court interpreters in languages of national minorities (Montenegrin, Bosnian), lack of training for available practitioners, low wages, often part-time employment at courts, no quality control only aggravate the situation in the industry that has been already in troubles upon recent reform in the justice system, recognized as failed by experts (Derikonjić, 2014). This means in the real life that cases are not translated, hearings are often postponed, and registered interpreters authorized by the Ministry of Justice cannot physically cope with their load.

Taking into account that sometimes case handling is deliberately delayed by parties, it should be said that due to minor differences between some languages (like Serbian and Bosnian as an example) a judge is entitled to decide whether a party demands an interpreter on purpose of making trials longer up to 'aging' of a case and punishment avoidance. In this case, the judge is entitled to defeat a motion (Tanjug, 2015).

In such a way, the given example (see more in Lysenko and Barbakov, 2016) proves that the government is pursuing a policy of guarantees of rights for citizens, in particular for representatives of national minorities to fair and equal legal proceedings and a gratuitous interpreter, but it is mostly and only remained on paper. It means that the state is unable to ensure enforcement for these rights.

\section{Discussion}

Unlike the abovementioned best legislation practices for rights of minorities protected by public authorities in the Republic of Serbia, Slovenia has chosen a different way regarding the Serbs. The Serbs (forty thousand people) in Slovenia so far have not received a status of a national minority. Without such the status, for example, children cannot have additional education in their native language. Representatives of other nations (the Italians, the Hungarians, the Gypsies) in Slovenia are ten times less in their number compared to the Serbs but it is generally believed that rights of such ethnic groups are better protected (Dmitrović, 2016) compared to rights of the Serbs. The Serbs, the Bosnians, and the Croats are called there 'new ethnic communities' or 'new minorities'. Such the terminological confusion was available as early as in 2003-2004 at the highest level (Committee on the Elimination of Racial Discrimination, 2004).

Some experts believe that now in the language policy of the Republic of Slovenia the situation in changing for the better to a certain extent: a negative attitude towards speakers of Serbo-Croatian is going away giving place to a neutral attitude towards them as towards speakers of any other foreign language (Požgaj Hadži, 2013).

\section{Conclusions}

The recent language policy of the Serbian government has been following up the language policy of the SFRY with its declared equality of languages in terms of strategic multilingualism. Example of Slovenian as a language of a national minority limited in a number of people confirms this with regard to cultural autonomy, legal equality, involvement in local governance and elective state bodies.

The language policy of the Republic of Serbia refers to a process of rapprochement with the EU, reforms in the justice system, as well as it takes into account needs of the market and the globalized world. At the level of legislation, we can call measures taken by the government consistent, constructive and promising in spite of negative demographic trends obvious for specific ethnic groups and national minorities like the Slovenes. However, in the real life, at the level of implementation 
of government's resolutions, there has been still a number of remaining unsolved problems shown with cases from judicial practice.

\section{Bibliographic references}

ALPATOV, V.M. 2013. Language policy in the modern world: 'monolingual' and 'bilingual' practice and problem of linguistic assimilation. Comparative Politics, vol. 2, n. 12), pp. 11-22. https://goo.gl/ofcRhS

BASIC, G., ĐORĐEVIC, LJ. 2010. Ostvarivanje prava na sluzbenu upotrebu jezika i pisama nacionalnih manjina u republici srbiji. Zastitnik Građana. Beograd: Sluzbeni Glasnik. ISBN 978-86-87945-05-0.

BELIKOV, V.I., KRYSIN, L.P. 2001. Sociolinguistics. Moscow: Russian State University for the Humanities, pp. 263-264. ISBN 5-7281-0345-6.

BUGARSKI, R. 2002. Nova lica jezika: Sociolingvisticke teme. Beograd: Biblioteka XX vek. ISBN 86-7562-014-3.

BUGARSKI, R. 2014. Jezik, nacionalizam i rat na prostoru bivse Jugoslavije. Beograd: Filoloski fakultet, Univerzitet u Beogradu. https://goo.gl/iFouAn.

COMMITTEE ON THE ELIMINATION OF RACIAL DISCRIMINATION. 2004. Summary of the 1571th Meeting. Sixty-Second Session, February 26. CERD/C/SR.1571. https://goo.gl/iW1Gw4.

DERIKONJIC, M. 2014. Pravosuđe je pre reforme bilo bolje. Politika Online, April 13. https://goo.gl/oMJLco.

ĐUKANOVIC, M. 2016. Istorijat ucenja slovenackog jezika na univerzitetu u Beogradu. https://goo.gl/IQaJaa.

DMITROVIC, R. 2016. Ima jedna lekcija koju Srbija nikada nauciti nece. Intermagazin, 20. februara. https://goo.gl/bB9Kra.

FILIPOVIC, J. 2008. Beleske za predmet Sociolingvistika. Zimski semestar 2008. Jezicka Politika i Planiranje: Dokument br. 5. http://old.fil.bg.ac.rs. GOJKOVIC, N. 2016. Sistem zastite manjina u Republici Srbiji. https://goo.gl/uAkRNK.

ISMAILOV, B.I. 2008. Development of incentive schemes for participation of representatives from national minorities in electoral process in international law and legal practice abroad. Allpravo.Ru. https://goo.gl/0IeGd5.

KNEZEVIĆ, A. 2012. Slovenci u Srbiji. Prilog etnodemografskom proucavanju. Annales. Ser. Hist. Sociol, vol. 22, no. 1, pp.: 171-186. ISSN 1408-5348.

LAKCEVIC, S., et al. (Eds.) 2012. Ethnicity - data by municipalities and cities. The Statistical Office of the Republic of Serbia. Belgrade. ISBN 978-86-6161-025-7.

LYSENKO, O.A. - BARBAKOV, O. M. 2016. A Review of problems in legal interpreting. Journal of Advanced Research in Law and Economics, vol. VII, no. 5(19), pp. 1103-1109. doi: 10.14505/jarle.v7.5(19).16. ISSN: 2068-696X.

MARJANOVIC, V. 2016. Sezdeset godina posle Novosadskog dogovora i srpska jezicka politika danas. Magacinportal.org, 4. maja. https://goo.gl/E5rKu3.

NACIONALNI SVET SLOVENSKE NARODNE MANJSINE. 2016. O Nas. http://slovenci.rs.

POZGAJ HADZI, V. (Ed.). 2013. Jezik između lingvistike i politike. Beograd: Biblioteka XX vek. ISBN 978-86-7562-115-7.

REPUBLICKI ZAVOD ZA STATISTIKU. 2016. Popis 2011, 27. jula. http://popis2011.stat.rs.

ROUSSEAU, L.-Z. 2007. Development and implementation of language policy. In: Language Policy in the Modern World. Saint Petersburg, pp. 97-121.

SCHWEITZER, A.D. - NIKOLSKY, L.B. 1978. Introduction to Sociolinguistics. Moscow. 
SRPSKI JEZIK I JEZICKA POLITIKA. 2015. Sajamknjiga.rs, 31. oktobar. https://goo.gl/oImd9w.

TANJUG. 2015. Ministarstvo pravde trazi tumace za bosanski jezik. Politika Online, 1 juna. https://goo.gl/FJo1Ip.

VLADA REPUBLIKE SRBIJE. 2004. Nacionalne manjine. https://goo.gl/9ZbBXF.

VOJVODIC, O. 2015. Ceranje cirilice ili jugoslovenska jezicka politika.

Ognjenvojvodic.info, 23. jula. http://www.ognjenvojvodic.info.

Words: 3655

Characters: 24282 (13.4 standard pages)

Olga A. Lysenko

Assistant Lecturer,

Department of Linguodidactics and Translation,

MA-equivalent in Philology

Peter the Great St. Petersburg Polytechnic University

olgalyss@gmail.com

Oksana V. Tretyakova

Associate Professor, Department of Marketing and Municipal Administration, $\mathrm{PhD}$ in Sociology

Tyumen Industrial University 